\title{
CHEMICAL COAGULATION AND ELECTROCOAGULATION IN TREATMENT TECHNOLOGY FOR ENVIRONMENTAL GREEN COMMUNITY
}

Ahmed Abd El Maguid Mekawy

Housing \& Building National Research Centre, Egypt

Key Words: Industrial wastewater, treatment, chemical coagulation and electrocoagulation.

\section{ABSTRACT:}

There are wide range of wastewater treatment techniques emerging which include biological processes and physical-chemical processes. It is also includes techniques based on electrochemical technology which include electrocoagulation (EC). Electrocoagulation (EC) is becoming a popular process to be used for wastewater treatment. The objective of this study is to evaluate the EC \& CC for improving wastewater quality, such as increasing removal efficiencies of COD. Alum was used as coagulant for chemical coagulation process at various doses and various sedimentation time. Also the performance of the Electrocoagulation (EC) was examined at constant operation time, various current density and various sedimentation time. For each set of experiments COD were analyzed for both EC and CC. Steady state COD removal was achieved at Alum dose 60 and $120 \mathrm{mg} / \mathrm{l}$ and settling time stated from $180 \mathrm{~min}$. COD removal with the various settling time was examined by varying the applied current between $0.4,0.8,1.0,1.5$ and $2.0 \mathrm{~A}$ with constant operating time at 40 minutes followed be settling time till $240 \mathrm{~min}$. according to the results obtained in this study EC gave better performance on the COD removal ratio, EC was more effective with $45 \%$ than chemical coagulation.

\section{INTRODUCTION}

Calls to the treatment of industrial and domestic wastewater to avoid environmental pollution and contamination of pure water resources are becoming national and international issues. There is an urgent need to develop new and more effective technologies for purifying and cleaning wastewater before disposing into other water system. Electrocoagulation technology presents many advantages compared to chemical coagulation methods therefor it is becoming a popular method to be used for wastewater treatment (Ni'am et al. 2007). 
Both types of coagulation are based on the same principle: the addition of metallic ions (usually $\mathrm{Fe} 3+, \mathrm{Al} 3+$ ) into the treated wastewater in order to destabilize the electrical charge of the colloidal particles from water, leading to the formation of aggregates bigger than the initial colloids, which determines the sedimentation and water purification (Holt et al. 2002; Canizares et al. 2006; Canizares et al. 2007). The difference between these two processes consists in the way metal ions are added. In case of chemical coagulation, the reagents $(\mathrm{FeCl} 3, \mathrm{Al} 2(\mathrm{SO} 4) 3$, etc.) are directly added (Riera-Torres et al. 2010), while in case of electrocoagulation, the metallic cation is supplied by an electricity stream generated by the oxidation of the metallic electrode, producing the corresponding metal ions.

Electrocoagulation (EC) process is an environmentally-friendly method which has some advantages as: no need for chemicals addition; (Daneshvar et al. 2004) requires simple equipment and less space for installation; simple operation; (Kim et al. 2002) faster and more effective separation of the pollutants than chemical coagulation. Furthermore, it produces sludge with low water content in comparison with chemical coagulation; (Bayramoglu et al. 2007). In addition, this process has lower effluent total dissolved solids compared with chemical treatment methods, and can remove the smallest colloidal particles; (Mollah et al. 2001; Un et al. 2009)

Extensive EC studies were carried out in the latter half of the century in both the United States and the Soviet Union (Naje \& Abbas 2013). However, EC remains practically unused in water and wastewater treatment until the 21 st century and this was mainly due to the then-high investment and electricity costs (Koren \& Syversen 1995; Chen 2004; Holt et al. 2005). These economic facts gave other technologies an edge over EC.

During the recent decades, researches have revealed EC as an attractive and suitable method for the treatment of various kinds of wastewater, by virtue of various benefits including environmental compatibility, versatility, energy efficiency, safety, selectivity, amenability to automation, and cost effectiveness (Mollah et al. 2001; Chen 2004; Holt et al. 2005; Naje \& Abbas 2013). This process is characterized by simple equipment, easy operation, a shortened reactive retention period, a reduction or absence of equipment for adding chemicals and decreased amount of precipitate or sludge which sediments rapidly (Bayramoglu et al. 2006). 
The EC technology induces coagulation and precipitation of contaminants by a direct current electrolytic process followed by separation of flocculent without the addition of coagulation-inducing chemicals. The water is pumped through a unit in which electrodes made of iron or aluminum are installed. A direct current electric field is applied to the electrodes to induce the electrochemical reactions needed to achieve the coagulation. Compared with traditional flocculationcoagulation, electrocoagulation has also the advantage of removing the smallest colloidal particles; such charged particles have a greater probability of being coagulated and destabilized because of the electric field that sets them in motion. Electrocoagulation also has the advantage of producing a relatively low amount of residue. At its simplest, an electrocoagulation system consists of an anode and a cathode made of metal plates, both submerged in the aqueous solution being treated. The electrodes are usually made of aluminum, iron or stainless steel, because these metals are cheap, readily available, proven effective and non-toxic (Koren \& Syversen 1995; Chen 2004; Bayramoglu et al. 2006; Dohare \& Sisodia 2014).

There are various treatment parameters effects on efficiency of the Electro-coagulation in elimination of the contaminants from wastewater are as follows (Thakur \& Chauhan 2016):

1. Material of the electrodes can be Iron, Aluminum and/or inert material. Iron and Aluminum ions and hydroxides have different chemistries and applications.

2. $\mathrm{PH}$ of the solution influences the dissolution of electrodes and affects the potential of the colloidal particles and also on the speciation of metal hydroxides in the solution.

3. The amount of electrochemical reactions taking place on the electrode surface is proportional to Current density.

4. Treatment time is relative to the amount of coagulants formed in the Electro coagulation system and other reactions taking place in the system.

5. Temperature has an effect on formation of floc, conductivity of the solution and reaction rates. Depending on the pollutant, increasing temperature can have either good or bad effect on removal efficiency.

6. Electrode potential defines which reactions occur on the electrode surface.

7. Concentration of the pollutants affects the removal efficiency. 
8. Inter-electrode distance may have effect on efficiency of the treatment and electricity consumption.

EC has been successfully tested to treat various wastewater such as; textile wastewater, urban wastewater, landfill leachate, tar sand and oil shale wastewater, chemical fiber plant wastewater, yeast wastewater, food and protein wastewater, rendering wastewater, olive oil wastewater , petrochemical wastewater, restaurant wastewater, egg process wastewater, and oily wastewater (Can et al. 2006).

This chemical process involves destabilizing wastewater particles so that they aggregate during chemical flocculation. Fine solid particles dispersed in wastewater carry negative electric surface charges (in their normal stable state), which prevent them from forming larger groups and settling. Chemical coagulation destabilizes these particles by introducing positively charged coagulants that then reduce the negative particles' charge. Once the charge is reduced, the particles freely form larger groups. Next, an anionic flocculant is introduced to the mixture. Because the flocculant reacts against the positively charged mixture, it either neutralizes the particle groups or creates bridges between them to bind the particles into larger groups. After larger particle groups are formed, sedimentation can be used to remove the particles from the mixture (Sahu \& Chaudhari 2013).

\section{EXPERIMENTAL}

The aim of the experimental study was to assess the performance of EC to improve wastewater quality, through increasing removal efficiencies of COD and various sedimentation and compare this achievement with the traditional CC.

\subsection{EC Technique}

On passage of Direct Current (DC) in wastewater to be treated causes production of metal ions at the expense of anode as sacrificing electrode and hydroxyl ions at cathode as a result of water splitting. The direct current provides the electromotive force to drive the chemical reactions to produce metal hydroxides. The metal hydroxides produced act as coagulant/flocculent for the suspended solids to convert them into flocs of enough density to sediment under gravity (Samir 2015).

Generally, three main processes occur serially during electrocoagulation:

(a) Electrolytic reactions at electrode surfaces,

(b) Formation of coagulants in aqueous phase, 
(c) Adsorption of soluble or colloidal pollutants on coagulants, and removal by sedimentation or floatation.

In EC with electrical current flowing between two electrodes, coagulant is generated in situ by electrolytic oxidation of the anode material. With an iron anode, $\mathrm{Fe}(\mathrm{OH})_{\mathrm{n}}$ with $\mathrm{n}=2$ or 3 is formed at the anode (Daneshvar et al. 2003; Mollah et al. 2004).

\subsection{Reactions at Sacrificial Electrodes}

During EC, the following main reactions take place at the Iron electrodes (Kuokkanen et al. 2013).

Anodic reactions

Iron Electrode Anode:

$\mathrm{Fe} \rightarrow \mathrm{Fe}^{2+}+2 \mathrm{e}^{-}$

Cathode: $2 \mathrm{H}_{2} \mathrm{O}+2 \mathrm{e}^{-} \rightarrow \mathrm{H}_{2}+2 \mathrm{OH}^{-}$

Overall: $\mathrm{Fe}^{2+}+2 \mathrm{H}_{2} \mathrm{O} \rightarrow \mathrm{H}_{2}+\mathrm{Fe}(\mathrm{OH})_{2}$

OR

Anode: $\mathrm{Fe} \rightarrow \mathrm{Fe}^{3+}+3 \mathrm{e}^{-}$

Cathode: $3 \mathrm{H}_{2} \mathrm{O}+3 \mathrm{e}^{-} \rightarrow 1.5 \mathrm{H}_{2}+3 \mathrm{OH}^{-}$

Overall: $\mathrm{Fe}^{3+}+3 \mathrm{H}_{2} \mathrm{O} \rightarrow 1.5 \mathrm{H}_{2}+\mathrm{Fe}(\mathrm{OH})_{3}$

Electrochemically generated metal cations will react spontaneously

with $\mathrm{OH}^{-}$ions forming various monomeric and polymeric metal hydroxy species. Ferric ions generated electrochemically may form monomeric ions, ferric hydroxo complexes with $\mathrm{OH}^{-}$ions, and polymeric species. These species/ions are:

Monomeric species:

$\mathrm{Fe}(\mathrm{OH})^{2+}, \mathrm{Fe}(\mathrm{OH})^{2-}, \mathrm{Fe} 2(\mathrm{OH}) 24^{+}$

Polymeric species:

$\mathrm{Fe}(\mathrm{OH})_{4}{ }^{-}, \mathrm{Fe}\left(\mathrm{H}_{2} \mathrm{O}\right) 5 \mathrm{OH}_{2}{ }^{+}, \mathrm{Fe}\left(\mathrm{H}_{2} \mathrm{O}\right)_{4}(\mathrm{OH})_{2}{ }^{+}$

$\mathrm{Fe}\left(\mathrm{H}_{2} \mathrm{O}\right)_{8}(\mathrm{OH})_{2}{ }^{4+}$ and $\mathrm{Fe}_{2}\left(\mathrm{H}_{2} \mathrm{O}\right)_{6}(\mathrm{OH})_{4}{ }^{2+}$

Which further react to form $\mathrm{Fe}(\mathrm{OH})_{3}$. The formation of these complexes depends strongly on the $\mathrm{pH}$ of the solution. Above $\mathrm{pH} 9, \mathrm{Al}(\mathrm{OH})^{4-}$ and $\mathrm{Fe}(\mathrm{OH})^{4-}$ are the dominant species (Akbal \& Camci 2010).

Iron hydrolysis products then destabilize pollutants present in the solution, allowing agglomeration and further separation by settling or flotation. Destabilization is achieved mainly by means of two distinct mechanisms, i.e.

1. Charge neutralization of negatively charged colloids by cationic hydrolysis products; and 
2. "Sweep flocculation", where impurities are trapped and removed in the amorphous hydroxide precipitate produced.

Several factors such as $\mathrm{pH}$ and coagulant dosage have an impact on charge neutralization and sweep flocculation (Arega \& Chavan 2018).

\subsection{EXPERIMENTAL PILOT UNIT}

The experimental work has been conducted as follows:

Phase (A): Studying the performance of chemical coagulation (CC) at various alum doses and various sedimentation time, COD was analyzed by standard methods for each set of experiments.

Phase (B): The performance of the Electrocoagulation (EC) was examined at constant operation time, various current density and various sedimentation time, for each set of experiments COD was analyzed by standard methods.

\section{Wastewater Sample}

Wastewater was collected from the automatic slaughterhouse in El Menoufya governorate, Table-1 presents the characteristics of Poultry Plan's wastewater.

\section{Table -1 Characteristics of Poultry Plant Wastewater}

\begin{tabular}{|l|l|l|l|}
\hline \multirow{2}{*}{ Character } & \multirow{2}{*}{ Mean } & \multicolumn{2}{l|}{ Range } \\
\cline { 3 - 5 } & & Max & Min \\
\hline pH Value & $\mathbf{7 . 4 5}$ & $\mathbf{7 . 8 8}$ & $\mathbf{7 . 0 2}$ \\
\hline Total solids mg/L & $\mathbf{2 0 0 0}$ & $\mathbf{3 7 5 0}$ & $\mathbf{4 0 0}$ \\
\hline Suspended solids $\mathrm{mg} / \mathrm{L}$ & $\mathbf{7 5 0}$ & $\mathbf{1 5 0 0}$ & $\mathbf{1 7 0}$ \\
\hline COD $\mathrm{mg} / \mathrm{L}$ & $\mathbf{1 6 0 0}$ & $\mathbf{2 6 5 0}$ & $\mathbf{7 0 0}$ \\
\hline BOD $\quad \mathrm{mg} / \mathrm{L}$ & $\mathbf{9 0 0}$ & $\mathbf{1 5 0 0}$ & $\mathbf{2 5 0}$ \\
\hline Total phosphorus $\mathrm{mg} / \mathrm{L}$ & $\mathbf{1 2}$ & $\mathbf{1 7 . 1 5}$ & $\mathbf{6 . 1 5}$ \\
\hline Turbidity NTU & $\mathbf{7 0 0}$ & $\mathbf{1 1 0 0}$ & $\mathbf{4 0 0}$ \\
\hline
\end{tabular}

\section{Experimental works sequences for $\mathrm{CC}$ :}

- The Alum solution was rigorously stirred at a stirring speed of $150 \mathrm{rpm}$ for $3 \mathrm{~min}$. in order to make certain that the chemicals are evenly and homogeneously distributed throughout the wastewater and followed by flocculation basin for $30 \mathrm{~min}$. duration time with different Alum dose of 45, 60, $120 \mathrm{mg} / \mathrm{l}$.

- Following flocculation process, wastewater was placed in graduated sedimentation columns 240 min settling time, the solution is mixed again, but this time in a slow fashion, to encourage the formation of insoluble solid precipitates.

- Chemical Oxygen Demand COD was measured at each run.

\section{Experimental works sequences for $\mathrm{EC}$ batch reactor}

- The electrocoagulation (EC) unit was cylindrical glass cell (volume $2000 \mathrm{~mL}$ ). 
- There are two iron electrodes were used in the electrocoagulation tank one electrode was connected as anode and one as cathode.

- Electrodes dimensions were (130 $\mathrm{mm}$ x $50 \mathrm{~mm}$ x $4 \mathrm{~mm})$.

- The distance between both electrodes was $50 \mathrm{~mm}$.

- Electrodes were washed with acetone solution to remove surface grease before each run. At the end of run, the electrodes were washed thoroughly with water to eliminate any solid residues on the surface, and dried.

- Electrodes were placed in two liters of fluid wastewater and connected to terminals of a Power supply.

- Current density was varied from $0.4 \mathrm{~A}$ to $2.0 \mathrm{~A}$ and operating time 40 minutes.

- After EC process, wastewater were degassed under low stirring speed with an impeller velocity $30 \mathrm{rpm}$.

\section{RESULTS AND DISCUSSION}

\subsection{The performance of chemical Coagulation (CC)}

Chemical coagulation (CC) performance was examined at various alum doses of $45,60,120 \mathrm{mg} / \mathrm{l}$ and various sedimentation time, for each set of experiments COD were analyzed by standard methods. As shown from firs run an increase in COD removal amount achieved with increasing coagulation dose Figure- 1 till the steady state of COD removal at Alum dose 60 and $120 \mathrm{mg} / \mathrm{l}$ and settling time stated from $180 \mathrm{~min}$. At settling time 240 min COD removal ratio were $65.1 \%, 72 \%$ \& $73.2 \%$ with Alum dose 45, 60 and $120 \mathrm{mg} / \mathrm{l}$ respectively. In this study, the results showed that the optimum removal of COD was obtained at 60 $\mathrm{mg} / \mathrm{l}$ of coagulants dosages.

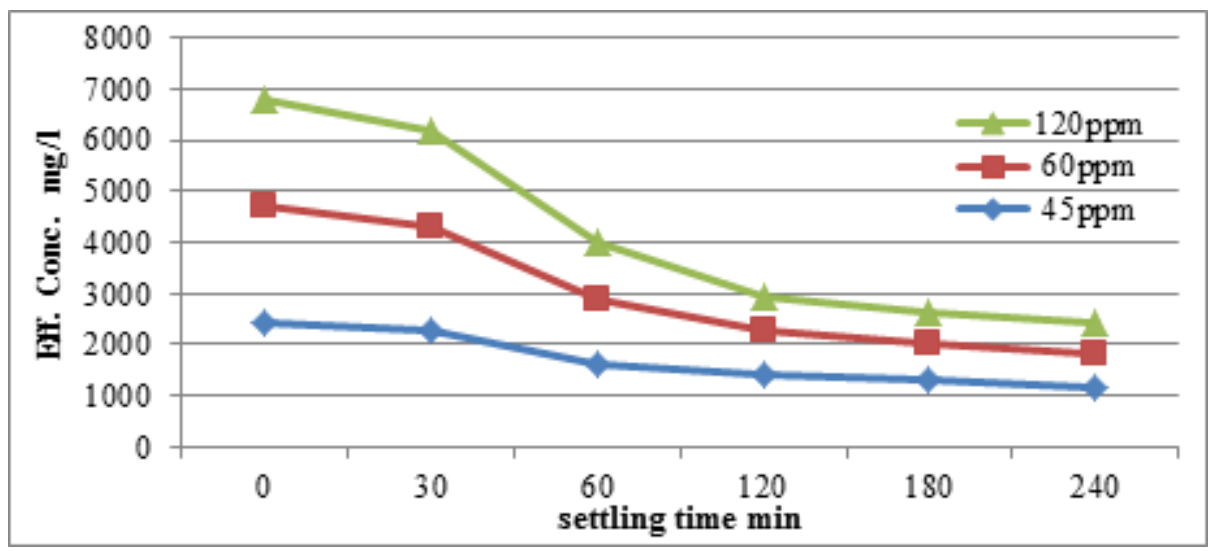

Figure (1) the performance of chemical coagulation (CC) 


\subsection{The performance of Electrocoagulation (EC)}

The effect of current density on the reduction of metal ions from wastewater in the batch reactor was studied with different current densities (CD), constant operation time, and various sedimentation time. The effect of current density on the COD removal with the various settling time was investigated by varying the applied current between 0.4 , $0.8,1.0,1.5$ and $2.0 \mathrm{~A}$ with constant operating time at 40 minutes followed be settling time till $240 \mathrm{~min}$ as shown in Figure 2.

The COD removal efficiencies increase as the settling time is increased. Result showed that the efficiency of EC with current density of 1.5 AMP was $87.0 \%$ when settling time was approximately 120 minutes with minor increasing to $90.5 .0 \%$ when settling time increase to 240 min.

For the current density of $0.4,0.8$ and 1.0 AMP, the COD removal percentage was 43,65 and $75 \%$ when settling time was 240 minutes. From the above results, the more favorable percentage removal of COD at 1.5 AMP $\left(5.26 \mathrm{~mA} / \mathrm{cm}^{2}\right)$ of current density.

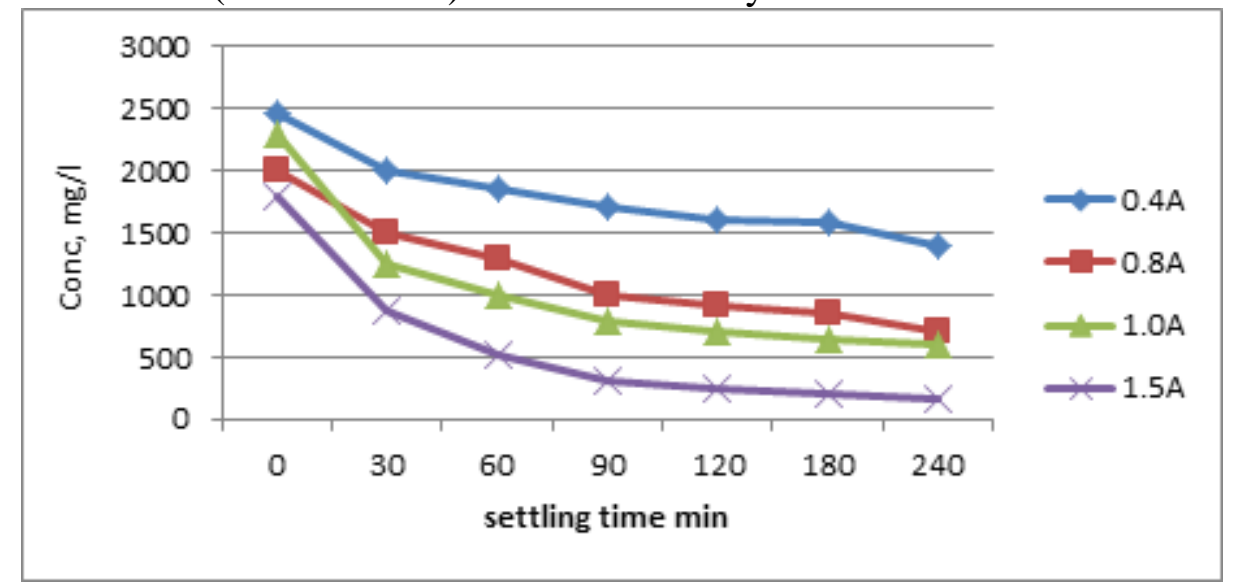

Figure (2) the performance of the Electrocoagulation (EC)

When the electrolysis time increases, the concentration of metal ions and their hydroxide flocs increases; thus, the COD removal efficiencies increase, It was found that as the value of current increased the COD removal efficiencies increased. This behavior is due to the applied current density that determines the coagulant dosage rate, the bubble production rate and size of flocs growth resulting in a faster removal of pollutants (Chavalparit \& Ongwandee 2009; El-Ashtoukhy et al. 2013). In other words by increasing the current of the cell the 
amount of hydrogen bubbles at the cathode increases, resulting in a greater upwards flux and a faster removal of the pollutant and sludge flotation

\subsection{Technical comparison between $\mathrm{CC}$ and $\mathrm{EC}$}

The capability of EC versus CC and their consequent effect on COD removal for industrial waste has been examined. EC exhibited better COD removal ratio and it was more effective (42\%) than chemical coagulation. Alum showed poor COD removal, this could be due to competitive adsorption (Zaleschi et al. 2012). Compared electrocoagulation and chemical coagulation processes applied for wastewater treatment and found that the best performances were obtained for the electrocoagulation. The researchers suggested that the chemistry behind the EC process in water in such that the positively charged ions are attracted to the negatively charged hydroxides ions producing ionic hydroxides with a strong tendency to attract suspended particles leading to coagulation (Ukiwe et al. 2014).

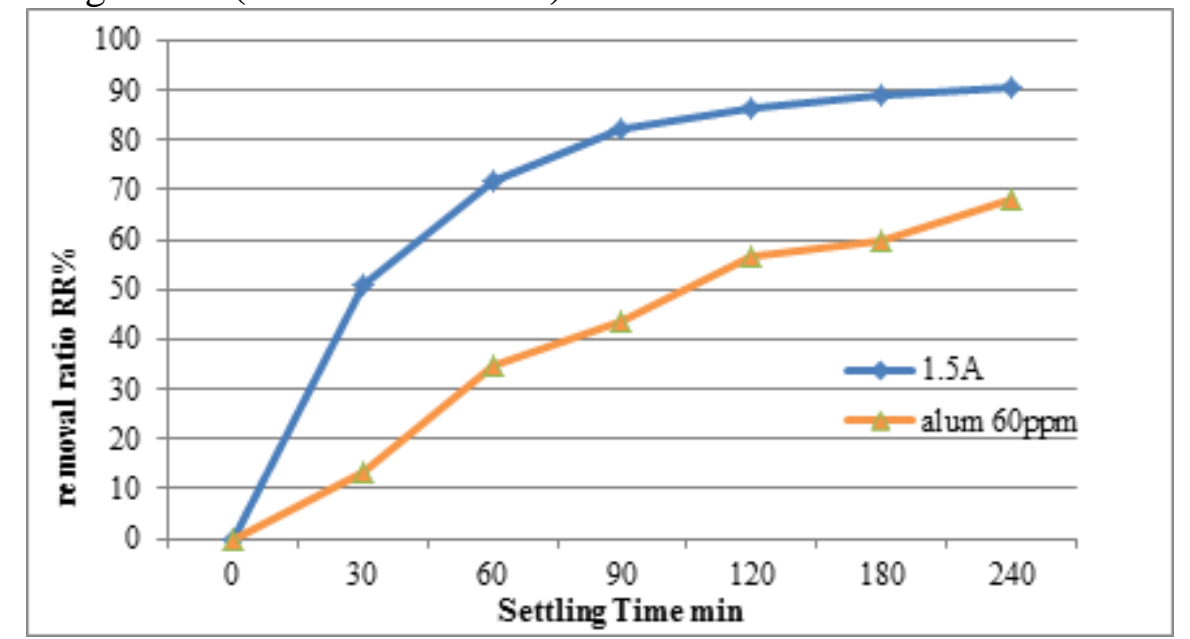

Figure (3) Technical comparison between CC and EC- COD removal ratio

\section{CONCLUSION}

The performances of the electrocoagulation and chemical coagulation process are comparatively presented, as suitable wastewater treatment processes for the improvement of water quality indicators.

1. At chemical coagulation (CC) the COD removal was increased with increasing the Alum coagulation dose. 
2. The COD removal efficiency using chemical coagulation at settling time 240 min were $52.1,70.4$ \& 71.2 with the different doses of Alum coagulant 45, 60 and $120 \mathrm{mg} / \mathrm{l}$ respectively.

3. It was deduced and found that the optimum and cost effective dose of alum is $60 \mathrm{mg} / \mathrm{l}$.

4. Using Electrocoagulation (EC) the COD removal efficiencies increase as the settling time is increased with constant operating time at 40 minutes.

5. It was found that the removal efficiency of COD increased with increasing current density.

6. For the current density of $0.4,0.8$ and 1.0 AMP, the COD removal percentage was 43,65 and $75 \%$ when settling time was 240 minutes.

7. COD removal efficiency using EC with current density of 1.5 AMP $\left(5.26 \mathrm{~mA} / \mathrm{cm}^{2}\right)$ was $89.0 \%$ when settling time was approximately 120 minutes with minor increasing to $91.0 \%$ when settling time increased to $240 \mathrm{~min}$.

8. The EC cell with current density of 1.5 AMP $\left(5.26 \mathrm{~mA} / \mathrm{cm}^{2}\right)$ was more effective in removing COD.

9. COD removal percentage was $91.0 \%$ at settling time $240 \mathrm{~min}$ using EC process with current density of 1.5 AMP and it was 70.4 $\%$ using $\mathrm{CC}$ process.

10. COD effluent concentration was $730 \mathrm{ppm}$ using EC process at settling time $240 \mathrm{~min}$ with $1.5 \mathrm{AMP}$ and was $170 \mathrm{ppm}$ using CC process.

The comparison of electrocoagulation and chemical coagulation processes used for the treatment of wastewater demonstrated the advantage of electrocoagulation treatment in improving wastewater quality, through increasing removal efficiencies of COD and various sedimentation.

\section{REFERENCES}

Ni'am, M.F. ; F.Othman ; J. Sohaili and Z. Fauzia (2007). Removal of COD and turbidity to improve wastewater quality using electrocoagulation technique. Malays J Anal Sci, 11(1): 198-205.

Canizares, P. ; F. Martinez ; J. Lobato and M.A. Rodrigo (2006). Electrochemically assisted coagulation of wastes polluted with Eriochrome Black T. Industrial \& Engineering Chemistry Research, 45(10): 3474-3480.

Cañizares, P. ; C. Jiménez ; F. Martínez ; C. Sáez and M. A. Rodrigo (2007). Study of the electrocoagulation process using aluminum and iron electrodes. Industrial \& Engineering Chemistry Research, 46(19): 6189-6195. 
Holt, P.K. ; G.W. Barton ; M. Wark and C.A. Mitchell (2002). A quantitative comparison between chemical dosing and electrocoagulation. Colloids and Surfaces A: Physicochemical and Engineering Aspects, 211(2-3): 233-248.

Riera-Torres, M. ; C. Gutiérrez-Bouzán and M. Crespi (2010). Combination of coagulation-flocculation and nanofiltration techniques for dye removal and water reuse in textile effluents. Desalination, 252(1-3): 53-59.

Daneshvar, N.; H.A. Sorkhabi and M.B. Kasiri (2004). Decolorization of dye solution containing Acid Red 14 by electrocoagulation with a comparative investigation of different electrode connections. Journal of Hazardous Materials, 112(1-2): 55-62.

Kim, T.H. ; C. Park ; E.B.Shin and S. Kim (2002). Decolorization of disperse and reactive dyes by continuous electrocoagulation process. Desalination, 150(2): 165-175.

Bayramoglu, M. ; M. Eyvaz and M. Kobya (2007). Treatment of the textile wastewater by electrocoagulation: economical evaluation. Chemical Engineering Journal, 128(2-3): 155-161.

Un, U.T. ; A.S. Koparal and U.B. Ogutveren (2009). Electrocoagulation of vegetable oil refinery wastewater using aluminum electrodes. Journal of Environmental Management, 90(1): 428-433.

Mollah, M.Y.A. ; R. Schennach ; J.R. Parga and D.L. Cocke (2001). Electrocoagulation (EC) - science and applications. Journal of Hazardous Materials, 84(1): 29-41.

Naje, A.S. and S.A. Abbas (2013). Electrocoagulation technology in wastewater treatment: a review of methods and applications. Civil and Environmental Research, 3(11): 29-42.

Holt, P.K. ; G.W.Barton and C.A. Mitchell (2005). The future for electrocoagulation as a localised water treatment technology. Chemosphere, 59(3): 355-367.

Chen, G. (2004). Electrochemical technologies in wastewater treatment. Separation and purification Technology, 38(1): 11-41.

Koren, J.P.F. and U. Syversen (1995). State-of-the-art electro flocculation. Filtration \& Separation, 32(2): 153-146.

Bayramoglu, M. ; M. Kobya ; M. Eyvaz and E. Senturk (2006). Technical and economic analysis of electrocoagulation for the treatment of poultry slaughterhouse wastewater. Separation and Purification Technology, 51(3): 404-408.

Dohare, D. and T. Sisodia (2014). Applications of Electrocoagulation in Treatment of Industrial Wastewater. A Review International Journal of Engineering Sciences \& Research Technology, 3: 379-386. 
Thakur, S. and M.S.Chauhan (2016). Treatment of Wastewater by Electro coagulation: A Review. International Journal of Engineering Science and Innovative Technology, 5: 104-110.

Can, O.T. ; M. Kobya ; E. Demirbas and M. Bayramoglu (2006). Treatment of the textile wastewater by combined electrocoagulation. Chemosphere, 62(2): 181-187.

Sahu, O. P. and P. K.Chaudhari, (2013). Review on chemical treatment of industrial waste water. Journal of Applied Sciences and Environmental Management, 17(2): 241-257.

Samer, M. (2015). Biological and Chemical Wastewater Treatment Processes, Wastewater Treatment Engineering, Associate Prof. Mohamed Samer (Ed.), InTech, DOI: 10.5772/61250.

Mollah, M.Y. ; P. Morkovsky ; J.A. Gomes ; M. Kesmez ; J. Parga ; and D.L.Cocke (2004). Fundamentals, present and future perspectives of electrocoagulation. Journal of Hazardous Materials, 114(1-3): 199-210.

Daneshvar, N. ; H. Ashassi-Sorkhabi and A. Tizpar (2003). Decolorization of orange II by electrocoagulation method. Separation and purification Technology, 31(2): 153-162.

Kuokkanen, V. ; T. Kuokkanen ; J. Rämö and U. Lassi (2013). Recent applications of electrocoagulation in treatment of water and wastewater - a review. Green and Sustainable Chemistry, 3(2): 89-121.

Akbal, F. and S. Camci (2010). Comparison of electrocoagulation and chemical coagulation for heavy metal removal. Chemical Engineering \& Technology, 33(10): 1655-1664.

Arega, Y. and R.B. Chavan (2018). Electrocoagulation Followed by Ion Exchange or Membrane Separation Techniques for Recycle of Textile Wastewater., Advance Research in Textile Engineering, 3 (2): $1-12$

Chavalparit, O. and M. Ongwandee (2009). Optimizing electrocoagulation process for the treatment of biodiesel wastewater using response surface methodology. Journal of Environmental Sciences, 21(11): 1491-1496.

El-Ashtoukhy, E.S.Z. ; Y.A. El-Taweel ; O. Abdelwahab and E.M. Nassef (2013). Treatment of petrochemical wastewater containing phenolic compounds by electrocoagulation using a fixed bed electrochemical reactor. Int. J. Electrochem. Sci, 8(1): 1534-1550.

Zaleschi, L. ; C. Teodosiu ; I. Cretescu and M.A. Rodrigo (2012). A comparative study of electrocoagulation and chemical coagulation processes applied for wastewater 
treatment. Environmental Engineering \& Management Journal (EEMJ), 11(8): 1517-1525.

Ukiwe, L.N. ; S.I. Ibeneme ; C.E. Duru ; B.N. Okolue ; G.O. Onyedika and C.A. Nweze (2014). Chemical and Electrocoagulation Techniques in Coagulation-Floccculation in Water and Wastewater Treatment-A Review. Journal: Journal of Advances in Chemistry, 9(3): 1988-1999.

التخثير الكيميائي والتخثير الكهزبي في تكنولوجيا المعالجة

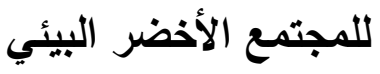

$$
\text { احمد عبد المجيد مكاوي }
$$

استاذ مساعد في الهنسة الصحية والبيئية - المركز القومي لبحوث الإسكان والبناء ، مصر فئر

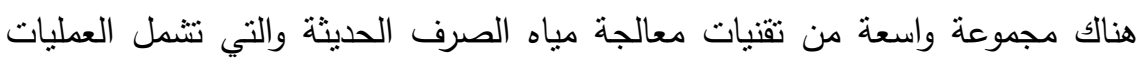

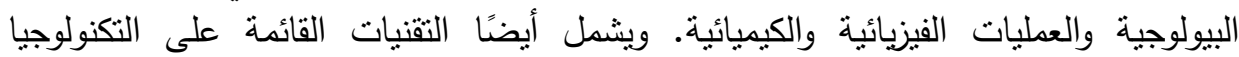

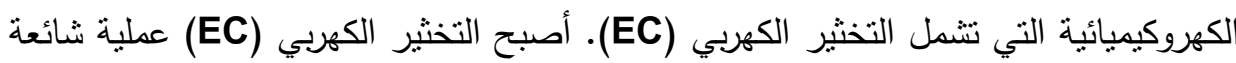

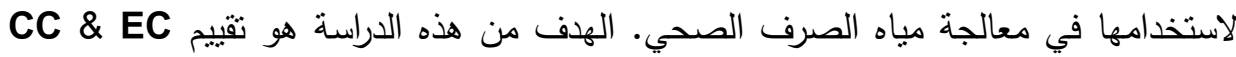

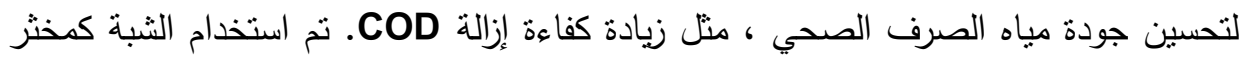

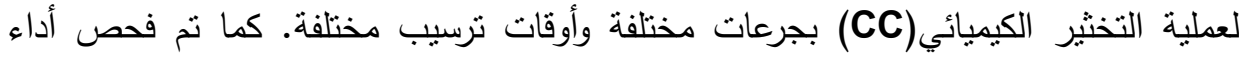
التختير الكهربي (EC) في وقت التتغيل المستمر ، وكثافة التنار المختلفة ووقت الترسيب

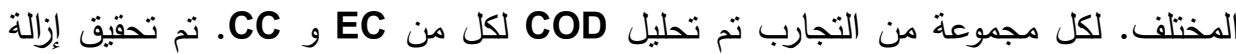
COD

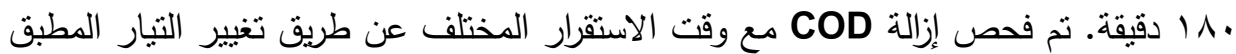

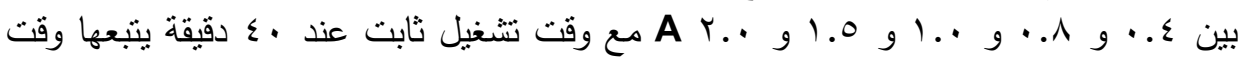

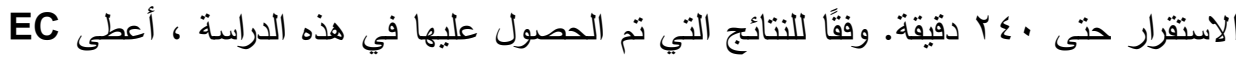

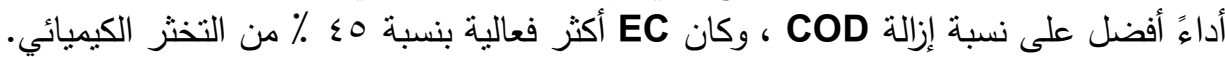

